\title{
Gendered small-business assistance: lessons from a Swedish project
}

\author{
Malin Tillmar
}

\section{Linköping University Post Print}

\section{Tweet}

N.B.: When citing this work, cite the original article.

Original Publication:

Malin Tillmar, Gendered small-business assistance: lessons from a Swedish project, 2007, Journal of European Industrial Training, (31), 2, 84-99.

http://dx.doi.org/10.1108/03090590710734327

Copyright: Emerald

http://www.emeraldinsight.com/

Postprint available at: Linköping University Electronic Press

http://urn.kb.se/resolve?urn=urn:nbn:se:liu:diva-36661 


\title{
Gendered small-business assistance
}

\section{-Lessons from a Swedish project}

\author{
Malin Tillmar, Ph. D., Ass. Prof. \\ Department of Management and Economics \\ Linköping University \\ S-583 81 LINKÖPING \\ SWEDEN \\ e-mail: malti@eki.liu.se \\ tel: +4613281588
}

National Institutet for Working Life

Laxholmstorget 3

S-602 21 NORRKÖPING

e-mail: malin.tillmar@arbetslivsinstitutet.se

tel: +4611218914

fax: +4611218920

Malin Tillmar has a Ph. D. in Business Administration and she is Assistant Professor at the Department of Management and Economics, Linköping University as well as Researcher at the National Institute for Working Life. Her research focuses on prerequisites for entrepreneurship in different contexts as well as for trust between organizations. She is the winner of the FSF/NUTEK prize 2005 for young researchers within the field of entrepreneurship and small-business research. 


\title{
Gendered small-business assistance
}

\section{-Lessons from a Swedish project}

\begin{abstract}
This paper deals with the design of small-business training programs and focuses on women business owners, their real needs and the supply of adequate training. How and to what extent are client selection and support needs influenced by the gender system? Are special projects for advisory services to women business owners still needed in a country like Sweden, which is known for its relatively high equality between women and men? The paper is based on an in-depth study of an ambitious Swedish project to advise women business-owners. Lessons to be learned from that project are discussed. Interviews with the participating business-owners as well as with advisors, combined with observations during lectures and coaching sessions have been conducted. The study shows that even gender-conscious support organizations may have a biased process of client recruitment, leading to an unintended discrimination of women business owners. Furthermore, over and above meeting the same problems as men, the women in the project give witness to the subtle obstacles which originate in the gendersystem. There is a need for these business professionals to understand the gender system in order to stop it from draining their time and energy and to allow them to handle it more effectively. They also report a need for networking and exchanging experiences. Based on these findings, it is argued that special programs are still needed.
\end{abstract}

Key words: Small-business, training, gender, entrepreneurship, women 


\section{Introduction}

How best to support and educate entrepreneurs is on top of the agenda in academia as well as in policy and practice (Greene, Katz \& Johannisson, 2004). There is a multitude of support initiatives in most countries (Lundström \& Stevenson, 2005). Taking Sweden as an example, we see that as large companies and public sector organizations have rationalized their activities and reduced employment, small businesses have increasingly been regarded as significant (Ramström, 1997, cf Regeringens prop 2001/02:4). Small-business development is prioritized within industrial and regional as well as employment policies (Nutek, 2000; 2001; Regeringskansliet/Government Office of Sweden, 2005). Currently, the government is taking action to increase interest in entrepreneurship among young people, stimulate export among small- and medium sized firms, develop advisory and financial services for new businesses, facilitate the generational shift in small-businesses and stimulate product development in small businesses (Regeringskansliet/Government Office of Sweden, 2005). Small businesses also receive subsidised support from numerous public and private organizations as well as from different regional projects financed through the EU. However, there are still many barriers to the training of people involved in small businesses (Klofsten, 2000). In addition, small firms are unaware of what is available, have a shortage of resources and may distrust support organizations (Gibb, 1990).

There is wide agreement about the importance of women's businesses both in western economies and in developing countries. The Global Entrepreneurship Monitor (2001) argue that supporting women entrepreneurs ${ }^{1}$ is the best initiative a country can take to increase entrepreneurship. Due to their increasing numbers, women business owners have received increasing attention both in academia and in practice during the past twenty years (Stevenson, 1986; Caputo \& Dolinsky, 1998; Orhan, 2001).

Of the Swedish businesses with fewer than 50 employees, $1 / 4$ are run by women (Nutek, 2003). They run businesses to a lesser extent then men, and could therefore account for a large portion of the new businesses the country needs, according to the Swedish Agency for

\footnotetext{
${ }^{1}$ This paper deals with support to women business owners. In the literature referred to, the term entrepreneur is often used synonymous with small-business owner/manager. When referring to such sources, the term entrepreneur is used in this way although my own view is that a business owner does not need to be entrepreneurial and vise versa. For the same reason the term female business owners is sometimes (when referring) used synonymous with women business owners, although a woman does not necessarily display female characteristics.
} 
Economic and Regional Growth (Nutek, 2003). To take advantage of this potential, it is vital to find the best ways of supporting these businesswomen. Apart from the general support options, there is also special assistance directed towards female business owners.

Previous research is inconclusive as to the characteristics of female entrepreneurs. The debate was long founded on whether they were similar or dissimilar to male entrepreneurs (Birley et al, 1987; Kolvereid et al, 1993; Lee \& Rogoff, 1997). Their personal value system was discussed (Olson \& Currie, 1992), as well as the role of the financial and human capital of their husbands (Caputo \& Dolinsky, 1998). Common to many of the studies is an underlying and unquestioned androcentric norm against which the women are compared. In recent years, most articles have centred on access to finance (Orhan, 2001) or support to women's businesses in transitional (Bliss \& Garratt, 2001) and developing countries (Munshi, 1999). In the western context policy makers have questioned whether special training and advisory services to women business owners is still needed (cf Wilson et al, 2004).

This paper sets out to explore the gender aspects of designing small-business training in a western context, through an in-depth study of a special project for women business owners managed by the large Swedish business support organization, Almi. More specifically, the aim is to analyze if and how such a project and the support needs of its participants are influenced by the gender system.

The case of Sweden is particularly interesting since it is a relatively well-functioning welfarestate (Esping-Andersen, 1996), with quality childcare and is known for high equality between men and women. The organisation, Almi, is state-owned and has an important role in implementing the government-initiated actions discussed above (Regeringskansliet/Government Office of Sweden, 2005).

Questions that will be dealt with are the following; To what extent and how was the project and the client selection influenced by the gender-system? Did the women business owners have special support needs? Which lessons can be learned from the project? If special advisory services directed at women entrepreneurs is still needed also in the western context, why is that, and what is the most important thing to consider in such initiatives? What needs to be improved and why? 


\section{Methodology}

The traditional domination of positivist approaches in entrepreneurship and small-business research has shifted somewhat since Gartner (1989) argued that focusing the dynamic, complex and lived experience of entrepreneurship might provide us with richer insights into the phenomenon. Slowly, there has been growing support for actors taking part in the research process for example (Fuller \& Moran, 2001; Johannisson, 2005) and for the use of narrative approaches (Steyaert and Bouwen, 1997; Rae, 2000; Warren, 2004). The Nordic and European research tradition in the field has especially has signalled the need for proximity to what we study (Hjort, Johannisson \& Steyaert, 2003).

This paper builds on a qualitative case-study of a special project aimed at supporting smallscale women business owners. The researcher followed the project and its participants as an observer from its start in mid 2002 until its finalization at the beginning of 2004. Apart from observations during seminars and counselling, semi-structured interviews with the 15 participants and the four advisors have been the main method. The collection of this empirical material can be divided into three distinct phases; the introductory phase during autumn 2002, the work-in-progress phase during 2003 and the follow-up phase in January 2004. These are summarized in figure 1.

\begin{tabular}{|l|l|l|l|}
\hline Phases & Time period & Main research method & Issues in focus \\
\hline $\begin{array}{l}\text { Phase 1 } \\
\text { Introductory }\end{array}$ & $\begin{array}{l}\text { September December } \\
2002\end{array}$ & $\begin{array}{l}\text { Semi-structured } \\
\text { interviews }\end{array}$ & $\begin{array}{l}\text { Advisors } \\
\text { Background } \\
\text { Project start-up } \\
\text { Working with women } \\
\text { business owners } \\
\text { Participants } \\
\text { Expectations } \\
\text { Business problems } \\
\text { Support needs } \\
\text { Being a woman in } \\
\text { business }\end{array}$ \\
\hline $\begin{array}{l}\text { Phase 2 } \\
\text { Work-in-progress }\end{array}$ & $\begin{array}{l}\text { Continuous during } \\
\text { 2003 }\end{array}$ & $\begin{array}{l}\text { Observations, } \\
\text { Unstructured dialogues }\end{array}$ \\
\hline $\begin{array}{l}\text { Phase 3 } \\
\text { Follow-up }\end{array}$ & $\begin{array}{l}\text { Semi-structured and Methods } \\
\text { of the project. }\end{array}$ \\
telephone interviews & $\begin{array}{l}\text { Experiences and } \\
\text { Reflections on the } \\
\text { project. } \\
\text { Change in views } \\
\text { compared to phase 1. }\end{array}$ \\
\hline
\end{tabular}

Figure 1: Phases of empirical research 
In Phase 1, personal interviews lasting on average two hours, were conducted with the four business advisors involved in the project ${ }^{2}$ as well as with six of the participating business owners. These six owners were selected on the criteria that they were just starting to meet their advisor, or coach, as the advisors were called in the project. The motive for this was to capture their expectations and support needs at an early stage, before becoming influence by the actual content of the project. The discussions revolved around the issues listed in the figure above and were taped and subsequently transcribed.

During phase 2, I observed the six seminars arranged by the project as well as three "coachmeetings” (see coming section), that is to say one meeting per active coach in the project. The content and methods of the coaching and seminars as well as the group interactions were observed. On these occasions, I also had informal conversations with participants and coaches to discuss their experiences and reflections about the project and its development.

The activities in the project were finalized in December 2003, and in January 2004, follow-up interviews were conducted with all 15 project participants. The aim was to capture their experiences and reflections over the advantages and disadvantages of the project as well as any changes in their need for support, view of business problems and experiences of being a business woman. Since the researcher at this time was well acquainted with the (somewhat geographically dispersed) participants, these interviews were conducted by phone. The length of the interviews varied from 15 minutes to one hour.

We should notice also that the linear image promoted above to show the empirical phases, is not very informative either of the underlying research process or of how this paper has progressed. In the empirical work, action (interviewing) and reflection (interpretation) were interchangeably in focus (Molander 1993). More generally, I would characterize the research process as abductive (Alvesson \& Sköldberg 2000) involving the interplay of deductive and inductive phases. The researcher had knowledge about small-business development as well as of gender and training before conducting the empirical study. Yet, it is the experiences recorded by the participants that have been central during the research process. More focused

\footnotetext{
${ }^{2}$ Three of these were actively working with the project, whereas the fourth was an important actor in the initiation of the project but on maternity leave during implementation.
} 
literature studies were subsequently conducted, guided by the themes brought up by the informants.

This longitudinal in-depth approach, with near-ethnographic components, makes this study original. The method brought me close to the project with its advisors and participants. It enabled me to capture and understand what happened and what did not happen over time in the minds of those involved, regarding issues that are not always easy to talk about. Of course, a coin always has a flipside. This paper will not present any statistically valid generalizations. Reliability and validity in this kind of study are instead acquired by providing as rich empirical descriptions and as many illustrative quotes as possible in the article format.

A more extensive account of the research, including further quotes supporting the arguments presented here, can be found in the Swedish report “To support women's businesses: Lessons form the Disa-project” (Tillmar, 2004). While the report reflects a broader approach and focuses also on the more detailed training and advisory techniques used, this article centres on the gender aspects of small-business support and the need for special programs for women business owners.

\section{Similar or dissimilar?}

Many of the previous articles published about female entrepreneurs, were published in the 90's and are interested in measuring whether women are similar or dissimilar to male entrepreneurs. Although this is the most common research question, contrary to expectations, few such differences were found, as concluded in a discourse analysis by Ahl (2004) ${ }^{3}$. Birley et al (1987) set out to explore the need for female-specific programs through studying the differences between male and female entrepreneurs ${ }^{4}$. Overall, the many similarities found led to the conclusion that female-specific programs were not needed. The same conclusion is drawn by Lee \& Rogoff (1997) concluding that “overwhelmingly, men and women are more alike than they are different” (p 25). Kolvereid et al (1993) studied whether female

\footnotetext{
${ }^{3}$ There are a few exceptions to this general rule. According to Lee \& Rogoff (1997) women tend to have less business knowledge prior to their start-up. Comparing reasons for males and females to start home-based businesses, Holmes et al (1997) conclude that females wanted to spend time with the family and make money by working for themselves to a higher extent then men, who instead were retired or retrenched, or wanted greater control and independence.

${ }^{4}$ They examined differences concerning experience, premises, legal forms of business, customer profile, labour usage, speed of start-up and finance. The authors were surprised to find that males ran their businesses from home to a considerably higher extent than women, as well as that woman employed as many men in their businesses as male business owners did.
} 
entrepreneurs perceived their business start-up environment to be more constraining than male entrepreneurs, concluding there was a very weak effect of gender. Also a more recent Swedish survey (Nutek, 2003) found that the differences between sectors are far larger than differences based on gender. Yet, women were overrepresented in healthcare and retail and men in construction and manufacturing. Olson \& Currie (1992) investigated whether female personal values affect the business strategies used, but did not find a relationship. Despite the examples presented above, Carter et al (1997) for example, assume that women have a greater ability to handle multiple stakeholders simultaneously and conclude that in this way they benefit from using broad generalist strategies.

As concluded also by Cohen \& Jennings (1995) and Wilson et al (2004) among others, many studies and discussions on women entrepreneurs take their point of departure in an andocentric norm. Through a discourse analysis, Ahl (2004) identifies three strategies used in articles on female entrepreneurship to explain the failure to find differences. These are; making a mountain out of a mole-hill, stressing that women entrepreneurs are different from ordinary women and moulding an alternative female entrepreneur model based on the small differences found in combination with general knowledge on women’s life situations.

As early as in 1986 Stevenson argued that we need to move beyond focusing on whether women are the same or different from men as business owners. Differences in experience, strategies and abilities need not be sex-based. A comprehensive study of female businessowners in Sweden (Sundin \& Holmquist, 1989) showed that "multitude” characterized the group. The authors often encountered the view that the typical "female entrepreneur" should be a certain kind of person, which according to Holmquist (1995) shows the stereotyping of women in society.

Cohen \& Jennings (1995) point out the danger of treating women as a homogeneous grouping, when studying specific gender related problems. Saarinen (1989) also argued that the category "women" is heterogeneous and should be deconstructed. Yet, this does not preclude the point that what women with different backgrounds and preconditions have in common is that they are in different ways and through different cultures discriminated as women, she argues. 
Whether men and women are basically different or similar was a lively debate within feminist theory during the first part of the 80’s (Åsberg, 1998). The discussions that then came into focus concerned the societal structures and power-differences rather than their underlying reasons. Studies attempting to show that biological differences affect social behaviour have had many biases, which have been discussed at length by Fausto-Sterling (1985) among others. The view taken in this paper will thus be that humans are social and cultural beings and that it therefore appears too simplistic to reduce what is regarded as male and female to biology. Instead, these preconceptions are regarded as being primarily socially constructed and hence changeable. The term gender will be used to denote this social construction and to mark its difference from biological sex. As expressed by West \& Zimmerman (1987) "gender is not a set of traits, nor a variable, nor a role, but the product of social doings of some sort” (p. 129).

In line with the argument of Gartner (1989) we thus turn our focus from personal characteristics to organization and context. Organizational and social structures are by no means gender neutral (Acker, 1990). Instead, construction of hierarchies and the division of labour taking place within (and between) organizations are gendered processes.

\section{The gender-system in business}

Hirdman (1988) launched the term "gender-system”, which is built on the logics of segregation and hierarchisation. Segregation means that what is categorized as female is separated from what is categorized as male. The segregation is apparent on the labour market among both employees and business owners. Sweden, using Esping-Andersens (1996) terminology, is a Scandinavian Welfare Model, which has a relatively large public sector responsible for the care and welfare of the populous of all ages, and which is financed through taxes. There is thus low cost quality child-care, elderly-care etc available. Women's participation in the workforce is high (79\% compared to 84\% among men) (SCB/Statistics Sweden, 2004) and the societal gender contract in the Nordic countries is based on the idea that both women and men participate in working life (Aaltio \& Kovalainen, 2003). Yet, as noted also by Aaltio \& Kovalainen, the occupations are still highly segregated (SCB/Statistics Sweden, 2004). Of those employed in the health- and care sectors, 83 and $86 \%$ respectively are women and it is only in three occupations that there are between $40-60 \%$ of both sexes are employed (high-school teachers, cooks and auditors). 
Among businesses, the women-owned companies are overrepresented in sectors of healthcare and retail, while men to a higher extent are to be found within construction and manufacturing (Nutek, 2003). The segregation of male and female entrepreneurship is similar to the workforce in general. That is a global phenomenon demonstrating the rigidity of the gender structures (Aaltio \& Kovalainen, 2003). Segregation also leads to men and women having different kinds of networks which may potentially be disadvantageous for women (Aldrich, 1990).

Hiearchisation implies that what is male is more highly valued than what is female, and is taken as the norm in comparison. This is most apparent in salary-differences. Women's salaries in Sweden were 83\% of men's in 2002 (SCB/Statistics Sweden, 2004). The logic of hierarchisation is also illustrated in the gender queuing theory (Reskin and Roos, 1990) which implies that women's entry into a male dominated occupation has historically been associated with falling wages, loss of autonomy and deskilling. Bird \& Sapp (2004) argue that the principle is the same among businesses, with women being overrepresented in less profitable sectors and geographical areas.

Occupations are gender-labelled (Ahl, 2004, Schneider, 2004, West \& Zimmerman, 1987). Occupational stereotypes are also affected by the message conveyed in media, and even for example in cartoons (Workman \& Freeburg, 1997). Entrepreneurship and self-employment is strongly male-labelled (cf Cohen \& Jennings, 1995; Sundin, 2002). Sundin \& Holmquist (1989) found that many women did not want to be regarded as business people, since the strong male connotations of the word threatened the identity and self-esteem of their husbands. The researchers also encountered the view that female businesspeople hardly existed in the region, since for example hair-dressers were not real businesspeople (Holmquist, 1995). The perception of business operations and entrepreneurship as male is strong even today (Ahl, 2004, Nilsson, 2002, Sundin, 2002). Males dominate in numbers and they better fit the picture of the entrepreneur as a person who works almost 24 hours a day.

An example of the consequences of this male norm for business owners is brought up by Orhan (2001) who concludes that financial discrimination occurs as bankers tend to consider women entrepreneurs primarily as women, rather than as business owners. Another example is Weeks (2004) summary of the key challenges for women business owners; to be taken seriously as business owners, employers and contributors to economic growth. 


\section{The Disa project}

Almi is a government owned company which aims to help entrepreneurs, new businesses and existing businesses to grow, through a combination of advisory services and finance. Almi Östergötland, where this study was conducted, is one of 21 Almi companies in the country. In the county of Östergötland, women's businesses account for just above $20 \%$ of the total businesses (Nutek/Almi 2003), excluding family businesses registered by a male family member. The women's share of Almi's clients is $14 \%$ excluding special projects which they run and 34\% including these two projects (one of which is the Disa-project under study).

The project studied in this paper was called Disa and was initiated by a contact between an advisor and the head of equal opportunities at the County Administrative Board who was able to attract funds from Nutek (Swedish Agency for Economic and Regional Growth) for the project. Almi wanted to assess its methods and develop its work with female business owners.

The project was built up around the normal advisory technique used at Almi Östergötland, called coaching. The coach and the client have a future and development oriented dialogue where no pre-existing concepts or structures are used. The coach asks questions with "her hands behind her back" rather than giving the solutions. They meet about once a month, two hours each time, for one and a half years. Apart from this, the Disa participants were offered six half-day seminars on issues that were to be decided according to their requirements. For this, participants paid 250 EUROs.

Three coaches, one female and two males, were actively involved during the implementation of the project. Fifteen businesses participated; four in manufacturing, one in marketing, five in training and consultancy, two in retail, one in service and one in the IT-sector. They were all spread around the county of Östergötland. Companies ran by one woman, female companions as well as family businesses were included. Almi wanted the project participants to reflect their regular clients, with the only difference being that these should be women.

When selecting participants, they used central registers of all the businesses in the county where a woman was the contact person. Still, the coaches reported on difficulties in finding participants. They said that their requirements might have been too high since they wanted representatives from different sectors and different parts of the county as well as from 
businesses with a high potential. After a while, when they were in a hurry to start due to the project time, solutions for finding participants became pragmatic:

Then [a certain coach] realized that in [a previous clients business] there was at least a female chairman of the board.

Another previous client, a family business, was asked to join the project and eventually did so since it was the only possibility to continue with the coaching. They would however have preferred to pay the full price rather than be involved in a project for females. Several other previous clients were also transferred to the project. According to the coaches, Almi's clients are recruited from among those they know of themselves or who are recommended by their partners, such as banks, auditors and others in their network. One coach says:

Some people here think that a real businesses should be a certain way and it has a man in charge.

Another coach believed that Almi's statement that they should only work with businesses with growth potential, which do not only have a local market ${ }^{5}$, may also make women reluctant to contact them. Furthermore, what constitutes a local market is a matter of judgement. One coach says:

I experienced that a manicurist specialized in nail-sculptures was not allowed to participate since it was said she had a local market. Later, it appeared she both imported a lot of things and sold her products all over...so it was wrong. It is a question of preconceptions from the businesses themselves, from Almi and from others in our network.

Before the implementation of the project, the coaches had a so called "gender-seminar" amongst themselves. It was one of the coaches who shared his thoughts and life experiences about male and female issues with the two others. ${ }^{6}$

\section{Experiences of participants}

In the introductory phase, the business owners interviewed expressed problems with lack of time, high demands on themselves and difficulties with prioritizing among all their tasks. Several talked about a work-situation where they act as fire-brigade rather than having time for long-term and strategic considerations. They needed a push to sit down and reflect over

\footnotetext{
${ }^{5}$ This has long been the policy of Almi, but the criteria was under discussion when the study was conducted.

${ }^{6}$ One of the other coaches had previously, on her own initiative and mainly in her spare time, taken a short university course in gender in working life.
} 
their business. It is also lonely to be a business owner, and several lack someone to act as a sounding board.

The majority of the business owners highlight circumstances relating to the fact that they are women. One prominent theme was the attitudes of people in their working environment. One young business owner was sick and tired of meeting the attitude:

Oh, are you the CEO, I thought you were the secretary.

They witness to not being taken seriously as business owners and as managers.

In some way, they don't see the power in what is female.

I am a woman and I am young, so I have to fight three times as hard to prove my competence

Another theme was their experiences of their personal situation. Many struggled with a bad conscience both at home and at work, feeling that they could not do enough.

Since the participants did not pay much to enter the project, their expectations of the Disaproject were very low. Some mentioned the possibility of networking with others in the same situation. However, as the coaching and the seminars started, expectations were gradually increased.

As the project progressed, I witnessed that the coach-meetings varied greatly depending on both the coach and the participants. Some were structured which seemed to suit both parties, while some became unstructured depending on the needs and present day situation of the participant. Some meetings were task-oriented, while others centred on experiences and feelings. All 15 participants were very satisfied with the coaching. It had inspired many to either continue with coaching or to use external people for business development in other ways, such as though mentorship or board-work. The following comments are representative:

You hear yourself say things and start to think.

I am more open to cooperation now, and different ways of seeing things. I am not as blind to other ideas and ways of doing things any more.

With regard to the seminars, the majority would have preferred more opportunities for exchanging experience and for networking. The six afternoon seminars (covering sales, rhetoric, stress, leadership, customer orientation and board-work) with invited seminar-leaders 
varied in the teaching methods used. Some involved group discussions and some did not. Since attendance at the seminars was not a requirement for joining the project, this varied a lot. The seminars started at $1 \mathrm{pm}$ and ended around 4.30, with the only opportunity for networking being the coffee-break.

The first time, we talked in small groups to get to know each other. I would have liked more of that.

For those who got the opportunity to talk during coffee breads, this was valuable. On the issue of meeting scepticism from people around you as a female business owner, one participant for example said:

The others experience the same thing, and it felt good to realise that. You get confirmation that others experience it, but what do you do? It is important to discuss this issue, to strengthen female business owners.

A few others said that they met someone likeminded at the seminars, and hoped that they would have further contact. With regard to the content of the seminars, some brought up issues they found interesting, but there was no consensus among participants.

The business owners witnessed to changes in their way of looking at their business and themselves as managers. Several said they had got a more structured, goal oriented and professional approach as well as that they had strengthened and clarified their leadership role. However, the follow-up interviews did not reveal any changes in their view or reflections over being a woman and a business-owner. They were struggling with the same issues as before and reflected in the same way about those issues as before the project.

There is absolutely no difference.

\section{Discussion}

In this section, the gendered small-business assistance will be discussed. The gendered process of client selection will be analyzed, before we turn to the support needs of the participants and how these are affected by the gender system. Central issues regarding whether, and if so what kind of, specific assistance is still needed will be discussed.

\section{Client selection}

Almi Östergötland demonstrated a certain level of gender-consciousness both on management and coach-level simply by being interested in implementing the Disa-project, and putting in 
the time required to apply for funds. They also displayed a generous and open attitude through giving access to this study and by subsequently arranging several seminars to disseminate the lessons learnt both internally and externally. The analysis reveals that also in somewhat gender-conscious support organizations, the gender system with its principles of segregation and the male norm/hierarchisation has an effect even in the selection process.

In the client selection process, the very idea that the participants of the Disa-project should reflect the rest of Almi's clients could be discussed. It made the coaches look for businesses in the sectors that they are used to, that is for example not in healthcare nor so much in education and retail where women are overrepresented. They had trouble finding participants that were good enough for the project. In other words, higher requirements were placed on these potential female clients than on the norm, i.e. the "normal clients".

The policy of not working with businesses with a local market can be discussed from a gender perspective. According to the Swedish Agency for Economic and Regional Growth, 66\% of women and 59\% of men run their businesses with a local market (Nutek, 2003). Yet, the willingness to let the business grow is higher among women than among men (65\% compared to $62 \%)$.

When searching for clients, both in ordinary coaching services and subsequently for the Disa project, the Almi network and its coaches were used. Of the ten coaches at Almi Östergötland, seven were men. The network is composed of bankers etc, most of whom are male.

Unconsciously, the recruitment of clients is likely to be biased due to the male norm and the male gender labelling of entrepreneurship and business ownership. The most illustrative example of how the male norm and the male gender labelling of entrepreneurship affects the client selection of the support organization is perhaps the situation with the manicurist described above. A business which might have had a high potential for growth into a wide market was not included. The female gender-labelling of her sector is likely to have influenced perceptions of the potential for growth.

That this occurs in regular operations is only one consequence of the gender system, and is not surprising. This is one of the reasons why special programmes, parallel to mainstreaming attempts, are still needed to give women equal access to advisory services. It is especially worth noting that this bias occurs even in a special program for women business owners. The 
importance of raising the gender-awareness of the support organization before implementing special programs becomes apparent.

\section{Support needs}

As to the general problems encountered and support needed, the female small-business owners involved in this study reported the same issues as those often heard from male smallbusiness owners, according to both the researchers and the coaches. Small-business owners often have a need for a better structure in their business, for support and for encouragement to create long-term plans as well as someone to act as a sounding board (cf also Klofsten, 2000).

Apart from these general problems and corresponding support needs, the women business owners also need to handle the gender-system in society and the expressions of this that they encounter. For many of them, this need is difficult to consciously formulate and articulate since they do not have systematized knowledge about the system and its principles. The problems become apparent when talking to them about being a woman in business. Both the principles of segregation between what is regarded as male and what is regarded as female and hiearchisation/male norm are illustrated clearly in for example the quote:

Oh, are you the CEO, I thought you were the secretary.

Based on the experiences of the participants reported above, it can be concluded that the expressions of the gender-system and the male gender labelling of entrepreneurship, businessownership and leadership lead to additional problems faced by women in business. Although they are as heterogeneous a group as male business owners (cf Saarinen, 1989; Sundin \& Holmquist, 1989) what the women have in common is that they encounter problems due to the system that exists in society. This study shows that these encounters consume a considerable amount of the time and energy of this group of business owners.

One of the potential success factors behind entrepreneurship programmes is that they can define the real needs of the participants, who may not themselves be the best to articulate these, according to Klofsten (2000). It is thus the task of conscious business advisors and their organizations to identify the need for knowledge of the gender-system, and integrate this as a vital component in special programs for women business owners. This was not done in the Disa-project, and as it seems in the follow-up interviews, the business owners did not make progress in their way of thinking about being a woman and a business owner. Recall the 
remark of the person who, almost accidentally, had discussed these issues with another participant during a break:

The others experience the same thing, and that is good to know. You can confirm that others experience it, but what do you do? It is important to discuss this issue, to strengthen female business owners.

The need for knowledge and exchange of experience regarding the gender system is one reason for implementing special programs for women entrepreneurs. Though men would also benefit from such knowledge, the need is different among women and the exchange of experience is likely to be freer in a female-only group. However, special programmes need to include qualitative seminars and discussions about the gender-system as such, as well as the exchange of ideas for how to handle it.

If we turn our attention to the methods used in the Disa-project, the positive comments from all participants indicate that the coaching was very successful. Since the idea of the method is to adapt to the specific circumstances and the specific person, this kind of coaching seems to help avoiding both the pitfall of treating the business owners according to a male norm and the pitfall of treating them as a homogeneous group of women. The method enables not only so called single-loop learning, which implies an assimilation of information, but also the changes in assumptions and norms called double-loop learning (Argyris \& Schön, 1978, Warren, 2004). Even triple-loop learing, where individuals learn to reflect upon and question their values and ways of doing things may be achieved. One participant in the project for example, experienced that she had become more open to new ideas and perspectives.

Combined with gender-awareness, coaching has great potential to change the participants’ ways of thinking, not only about their business as such, but also about the gender issue. Double and triple loop learning both for general business problems and gender-related ones are also likely to be facilitated by allowing for organized exchange of experiences among participants. Recall from the previous section that most participants lacked opportunities for that and for networking. Networking has previously been found to be a key for successful support to women entrepreneurs (Carter \& Cannon, 1992; Cohen \& Jenings, 1995).

\section{Results and implications}

The main lessons to be learnt from the Disa project are summarized below. 
Since client selection tends to be biased, special support programs are needed to give women entrepreneurs the same opportunities for business support as men. However, this study shows that special programs are by no means a guarantee for an unbiased client selection. Support organizations need high levels of gender awareness in the early stages of the client recruitment process in order to avoid the pitfalls of the male norm. This includes not only being aware of their own prejudices before screening potential clients, but also looking for clients in other sectors than their usual and using other channels and contacts to find them.

Women business owners are just as heterogeneous a group as male business owners, but have in common the fact that they also encounter disadvantages originating from the gender-system in society. This consumes considerable time and energy, and they thus need help to identify the system and acquire strategies for how to handle it. I argue that special programmes for women business owners are needed to equip them with this. Succeeding in such a venture however requires highly knowledgeable coaches and seminar leaders. Business advisors in general, and those working in special programmes in particular, need adequate training in gender issues. When implementing special programs, the gender system should ideally be discussed during a seminar at an early stage, giving ample time for exchange of experiences. During coach-meetings, the coach can then raise the issue when needed.

The coaching method was successful since it seemed to help avoid both the pitfall of treating the business owners according to a male norm and the pitfall of treating them as a homogeneous group of women. Arguably, double- and triple-loop learning is facilitated by this method. The exchange of experiences and opportunities for networking is a method which could have been better utilized in the project. For this methodology to function, attendance during seminars could have been a requirement for participation in the project.

Let us finally recall that what has been analyzed is a special support program for women entrepreneurs in an organization displaying some amount of gender-awareness, undertaken in a welfare-state known for its equality between men and women. Since the gender-biased processes discussed in this study occur in such a context, I find it likely that it occurs in other contexts as well. (With the support of previous gender-research, I dare to say this despite the fact that this is a qualitative case-study). With regard to the question if special support programs for women entrepreneurs are still needed in the western context, I would thus say 
that this is the case. I wish to highlight however, that the arguments for continued special support to women business-owners are by no means arguments against efforts to increase the number of women served by regular operations. The results of the study presented here give equally strong support to the importance of gender awareness among mainstream business support providers. It is not a matter of one or the other. If we want to effectively support women business owners, we still need to work simultaneously with specific programs and a mainstreaming of the gender issues. 


\section{References}

Aaltio, I. and Kovalainen, A. (2003), "Using gender in exploring organizations, management, and change", in B. Czarniawska and G. Sevón (Ed.), The Northern Lights: Organization theory in Scandinavia, Liber Ekonomi, Malmö.

Acker, J. (1990), "Hierarchies, Jobs, Bodies: A Theory of Gendered Organizations", Gender \& Society, Vol 4 No 2, pp. 139-158.

Ahl, H. J. (2004), The scientific reproduction of gender inequality : a discourse analysis of research texts on women's entrepreneurship, Liber, Stockholm.

Aldrich, H. (1990), "Networking among women entrepreneurs", in O. Hagan, C. Rivchun and D. Sexton (Ed.), Women-owned businesses, Praeger, New York.

Alvesson, M. and Sköldberg, K. (2000), Reflexive Methodology: New Vistas for Qualitative Research, Sage Publications, London.

Argyris, C. and Schön, D. (1978), Organizational Learning: A Theory of Action Perspective, Addison-Wesley, Reading, MA.

Bird, S. R. and Sapp, S. G. (2004), "Understanding the gender gap in small business success Urban and rural comparisons", Gender \& Society, Vol 18 No 1, pp. 5-28.

Birley, S. and Saunders, P. (1987), "Do women entrepreneurs require different training?" American journal of small business, Vol 12 No 1, pp. 27-35.

Bliss, R. T. and Garratt, N. L. (2001), "Supporting Women Entrepreneurs in Transitioning Economies." Journal of Small Business Management, Vol 39 No 4, pp. 336-344.

Caputo, R. K. and Dolinsky, A. (1998), "Women's Choice to Pursue Self- Employment: The Role of Financial and Human Capital of Household Members." Journal of Small Business Management, Vol 36 No 3, pp. 8-17.

Carter, S. and Cannon, T. (1992), Women as Entrepreneurs, Academic Press Ltd, London.

Cohen, L. and Jennings, P. (1995), "Invisible entrepreneurs : issues, contexts and approaches in researching and supporting enterprising women - part 1", Business, growth and profitability, Vol 1 No 4, pp. 339-351.

Cohen, L. and Jennings, P. (1996), "Invisible entrepreneurs : issues, contexts and approaches in researching and supporting enterprising women - part II", Business, growth and profitability, Vol 2 No 1, pp. 63-74.

Esping-Andersen, G. (1996), Welfare states in transition. National adaptions in global economics., SAGE, London. 
Fausto-Sterling. (1985), Myths of gender: bilogical theories of women and men, Basic Books, New York.

Fuller, E. and Morgan, P. (2001), "Small enterprises as complex adaptive systems: a methodological question?" Entrepreneurship and Regional Development, Vol 13 No 1, pp. 47-63.

Gartner, W. (1989), "Who is an entrepreneur? Is the wrong question", Entrepreneurship Theory and Practice, Vol 11 No 3, pp. 47-68.

Gibb, A. A. (1990), "Design effective programmes for encouraging the small business start-up process", Journal of European Industrial Training, Vol 14 No 1, pp. 17-25.

Global Entrepreneurship Monitor, G. (2001), Executive report: Global Entrepreneurship Monitor, Babson College, Boston, MA.

Greene, P. G., Katz, J. A. and Johannisson, B. (2004), "From the Guest Co-Editors." Academy of Management Learning and Education: Special Issue on Entrepreneurship Education, Vol 4 No 3, pp. 238-41.

Hirdman, Y. (1988), "Genussystemet: reflexioner kring kvinnors sociala underordning", Kvinnovetenskaplig Tidskrift, Vol 3 No pp. 49-63.

Hjort, D., Johannisson, B. and Steyaert, C. (2003), "Entrepreneurship as Discourse and Life Style", in B. Czarniawska and G. Sevón (Ed.), The Northern Lights: Organization theory in Scandinavia, Liber Ekonomi, Malmö.

Holmes, S., Smith, S. and Cane, G. (1997), "Gender issues in home-based business operation and training: an Australian overview", Women in Management Review, Vol 12 No 2, pp. 68 73.

Holmquist, C. (1995), "Den kvinnliga företagaren: Kvinna och/eller företagare?" in E. Sundin (Ed.), Pengarna och livet: Perspektiv på kvinnors företagande, NUTEK, pp.

Johannisson, B. (2005), Entreprenörskapets väsen, Lund, Studentlitteratur.

Klofsten, M. (2000), "Training entrepreneurship at universities: a Swedish case." Journal of European Industrial Training, Vol 24 No 6/7, pp. 337.

Kolvereid, L. and Shane, S. (1993), "Is it equally difficult for female entrepreneurs to start businesses in all countries?" Journal of Small Business Management, Vol 31 No 4, pp. 42-51.

Lee, M.-S. and Rogoff, E. G. (1997), "Do women entrepreneurs require special training? : an empirical comparison of men and women entrepreneurs in the United States", Journal of small business and entrepreneurship, Vol 14 No 1, pp. 4-29.

Lundström, A. and Stevenson, L. A. (2005), Entrepreneurship policy: theory and practice, Springer, Boston, Mass.

Molander, B. (1993), Kunskap i handling, Daidalos, Göteborg. 
Munshi, Z. (1999), "Strategic Approaches to Development of Women Entrepreneurs", in B. S. Rathore and S. K. Dhameja (Ed.), Entrepreneurship in the 21st century, Rawat Publications, New Delhi, pp. 343-355.

Nilsson, P. (2002), in C. Holmquist and E. Sundin (Ed.), Företagerskan: Om kvinnor och entreprenörskap, SNS Förlag, Stockholm.

Nutek, S. B. D. A. (2000), Support services to SMEs: Analysis of market of support services in the context of the working group on the visibility and quality of support services, 2000:13.

Nutek, S. B. D. A. (2001), SME:s in Sweden: Structural Change and Policy Development, Swedish Business Development Agency, Infonr 20-2001.

Nutek. (2003), Kvinnors företagande - format av samhället, B 2003:7.

Nutek/Almi. (2003), Sammanställning av statistik kring kvinnors företagande i Östergötland,

Olson, S. F. and Currie, H. M. (1992), "Female entrepreneurs: personal value systems and business strategies in a male-dominated industry", Journal of Small Business Management, Vol 30 No 1, pp. 49-57.

Orhan, M. (2001), "Women Business Owners in France: The Issue of Financing Discrimination." Journal of Small Business Management, Vol 39 No 1, pp. 95-102.

Rae, D. (2000), "Understanding entrepreneurial learning: a question of how?" International Journal of entrepreneurial Behaviour and Research, Vol 6 No 3, pp. 145-159.

Ramström, D. (1997), "Småföretagsforskningen på nya vägar", in B. e. a. Person (Ed.), Småföretagande, entreprenörskap och jobben: ett forskningsfält i förändring, Rådet för arbetslivsforskning.

Regeringskansliet. (2005), Regeringens åtgärder för fler och växande företag, N5021.

Reskin, B. and Roos, P. (1990), Job queues, gender queues: Explaining women's inroads into male occupations, Temple University Press, Philadelphia.

Saarinen, A. (1989), "Kvinnorforskningens interventionsprojekt: problem och utmaningar", Kvinnovetenskaplig tidskrift, Vol 1989 No 3-4.

Scb. (2004), Lathund om jämställdhet, Enheten för demografisk analys och jämställdhet, Schneider, D. J. (2004), The Psychology of Stereotyping, The Guilford Press, New York.

Stevenson, L. A. (1986), "Against all odds: the entrepreneurship of women", Journal of Small Business Management, Vol 24 No 4, pp. 30-36.

Steyaert, C. and Bouwen, R. (1997), "Telling stories of entrepreneurship: towards a narrative contextual epistemology for entrepreneurial studies." in R. Dockels and A. Miettinen (Ed.), Entrepreneurship and SME Research, Aldershot, Ashgate, pp. 47-62. 
Sundin, E. and Holmquist, C. (1989), Kvinnor som företagare, osynlighet, mångfald, anpssning - en studie, Liber förlag, Malmö.

Sundin, E. (2002), "Företagandets manliga prägling: orsaker och konsekvenser", in C. Holmquist and E. Sundin (Ed.), Företagerskan: Om kvinnor och entreprenörskap, SNS Förlag, Stockholm.

Tillmar, M. (2004), Att stödja kvinnors företagande: Lärdomar från projektet DISA, Arbetets organisering och marknad, Norrköping, 2003:4.

Warren, L. (2004), "A systemic approach to entrepreneurial learning: An exploration using storytelling", Systems Research and Behavioral Science, Vol 21 No 1, pp. 3-16.

Weeks, J. (2004), "Support for women's entrepreneurship in the United States : lessons learned", in (Ed.), Access to financing and ITC for women entrepreneurs in the UNECE region : challenges and good practices, United Nations, Geneva, pp. 11-13.

West, C. and Zimmerman, D. H. (1987), "Doing Gender", Gender \& Society, Vol 1 No 2, pp. 125-151.

Wilson, L., Whittam, G. and Deakins, D. (2004), "Women's enterprise: a critical examination of national policies." Environment \& Planning C: Government \& Policy, Vol 22 No 6, pp. 799-815.

Workman, J. E. and Freeburg, E. W. (1997), "A Method to Identify Occupational Stereotypes", Family and Consumer Science Research Journal, Vol 25 No 4, pp. 390-411.

Åsberg, C. (1998), "Debatten om begreppen: "Genus" i Kvinnovetenskaplig tidskrift 19801998", Kvinnovetenskaplig Tidskrift. 